
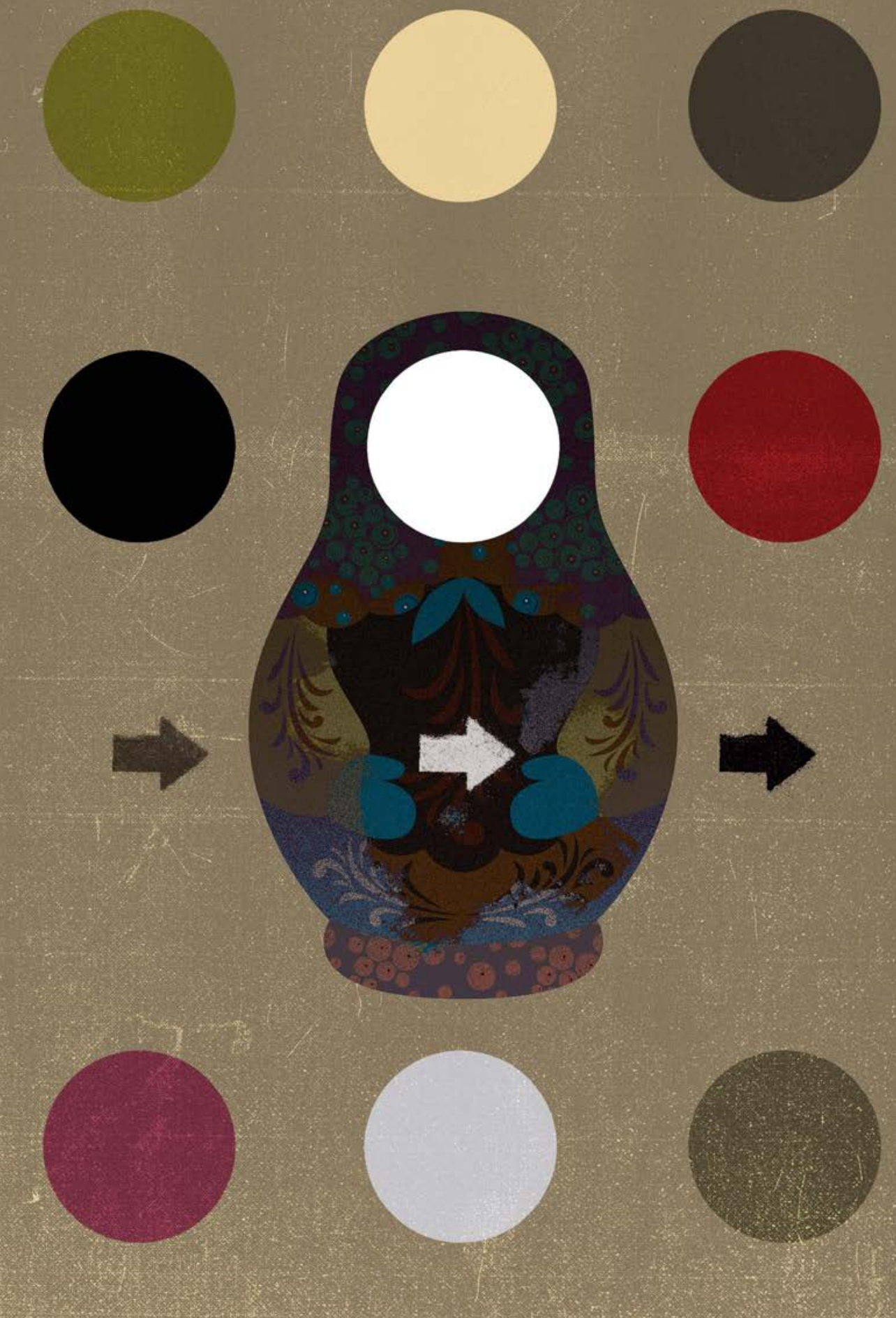

$r_{2}$ 


\title{
Political Conservatism in Russia
}

\author{
Conservadorismo Político na Rússia
}

${ }^{*}$ Maria Snegovara

\begin{abstract}
In this paper I discuss the conservative turn that took place in Russia in the last 15 years comparing it to the recent experience of Hungary and Poland. I show that to a large extent this backlash is of a socioeconomic nature and reflects the people's frustration with the downsides of the economic liberalization. Moreover, the depth of the original social transformation determined a society's ability to resist to the conservative trend. In Russia where the modernization processes were the shallowest, the old political elites could regain power sooner and roll back the society deeper. I also overview different conservative schools of thought in Russia and show Putin manipulated this ideology to strengthen his hold on power.
\end{abstract}

Keywords: conservatism, right populism, Eurasianism, sovereign democracy

\begin{abstract}
Resumo
Neste artigo discuto o giro conservador que teve lugar na Rússia nos últimos 15 anos, comparando-o com a experiência recente da Hungria e da Polônia. Mostro que, em grande parte, esta reação é de natureza socioeconômica e reflete a frustração das pessoas com as desvantagens da liberalização econômica. Além disso, a profundidade da transformação social original determinou a capacidade de uma sociedade para resistir à tendência conservadora. Na Rússia, onde os processos de modernização eram os mais superficiais, as antigas elites políticas podiam recuperar o poder mais cedo e reverter a sociedade mais profundamente. Também vejo diferentes escolas de pensamento conservadoras na Rússia e mostro que Putin manipulou essa ideologia para fortalecer seu domínio sobre o poder.
\end{abstract}

Palavras-chave: Conservadorismo, Populismo de direita, Eurasianismo, Soberania Democrática

\footnotetext{
* Ph.D. candidate at Columbia University (Comparative Politics and Statistical Methods) working on the sources of support for radical and populist right parties in Eastern Europe. She looks at the political strategies of the ex-Communist parties to explain the success of the radical right parties across Eastern Europe. Ms. Snegovaya research focus also includes the nuances of the Russian political system, Ukraine's domestic situation, and Russian-Ukrainian conflict. She also regularly contributes to publications including The Washington Post, Huffington Post, The New Republic, The National Interest and Vedomosti business daily. Contact: ms4391@columbia.edu
} 


\section{Introduction}

Since the mid-2010 the Freedom House reports the increasing number of the countries in the world experienced a serious decline in political freedoms. Eastern Europe is one of the regions with a decline in number of political freedoms in such countries as Hungary and Russia. Recently Poland joined the group, following the victory of the right-wing party Law and Justice (PiS) in the 2015 parliamentary elections. ' A number of disturbing similarities exists between Russia's recent political style, Hungarian and Polish leadership: the use of the Eurosceptic rhetoric (Müller 2016), illiberal tendencies including the attempts to destroy the system of checks and balances (Gostyńska-Jakubowska 2016). There is also an ideological sympathy between the leadership of these countries: the links between Vladimir Putin and Hungary's Viktor Orban are known; in 2011 the PiS leader Jaroslaw Kaczynski declared that "one day we will see Budapest in Warsaw (Gostyńska-Jakubowska 2016).

Hence though Russia was the first country in the region to embrace this illiberal trend, it was not unique. The checks and balances on president's authority were destroyed in the early 2000s after Vladimir Putin accession to power followed by his ideological embrace of the conservative trend. Yet, Russia has gone furthest along this track: unlike other countries Russia's system (which was never perfectly democratic) has transformed into a full-fledged electoral autocracy. Russia may also be purposefully contributing to the illiberal trends in other countries by funding populist parties and leaders. ${ }^{2}$ Yet as I argue Russia's path is the part of the same trajectory recently followed by other countries.

What explains the recent trend in these countries? In this paper I look at the explanations for the recent conservative trend in Russia in comparison to Poland and Hungary by focusing on the conservative demand and supply side. First, I look at the specific social prerequisites that made this illiberal trend possible. Second I analyze the specific incentives of the Russian elites that chose to use and manipulate the available social preconditions.

\section{Definitions}

The term conservatism is often associated to a wide range of ideological positions, including traditionalism, orthodoxy, nationalism, paternalism, right-wing politics etc. The variation of approaches to conservatism largely depends on the definition used, hence it is important to define the issue first.

Different approaches to conservatism can be broadly split into the ideological and the situational ones. The ideological approaches (starting with Burke's critic of the French Revolution) are associated to ideological movements that oppose modernism, liberalism and/or socialism in an attempt to return to the "good old times" and stress the importance of tradition (in the Mannheimian sense) (Mannheim 1953; Bloor 1997). 
Under this approach, conservatism is understood as initial reaction to the political and social change, a reaction which later evolved into a separate ideology, a distinct mode of thought, its own independent reflexive doctrine with an emphasize on specific values, traditions and institutions (such as importance of the moral order and hierarchy). What makes political arguments conservative (contrary to orthodoxy and traditionalism) is the critic of progressive and/or liberal arguments using "the enlightened grounds of the search for human happiness, based on the use of reason" (Muller 1997).

By contrast, Huntington (1957) understood conservatism as fundamentally a positional ideology that emerges as an outcome of distinct historical situations when a fundamental challenge to the established institutions forces supporters of such institutions to employ the conservative ideology in their defense. Therefore, to Huntington conservatism as a set of ideas designed to justify any established social order, "no matter where or when it exists, against any fundamental challenge to its nature or being, no matter from what quarter rather than an inherent theory in defense of particular values or institutions" (Huntington 1957). Under this approach conservatism is primarily a set of parallel ideological reactions to similar social situations, a passionate affirmation of the value of existing institutions, a defense of tradition that exists without tradition, which appears when "challenging and defending social groups stand in a particular relation to each other" (Huntington 1957: 456). In this sense conservatism is highly reactionary in nature, without any unifying ideological grounds.

For the purposes of this work I will use Huntington's situational interpretation of conservatism, which will allow me to explain the fundamentally changeable and instrumental application of conservatism by the Russian leadership. In my view, the conservative turn in Russia represents an attempt by the Russian elites and some groups of the Russian society to resist the social transformation that began in the late 1980s - early 1990s. In this sense, conservatism in today's Russia is fundamentally instrumental in nature (despite its relies on some philosophical tradition). Such approach allows to explain the inconsistency and fragmentation in today's Russian conservative tradition.

\section{Demand Side: Social Fatigue from Transformation}

The emergence of a conservative trend in Russia. Hungary and Poland (I label them as the "right" due to their active use of the nationalist rhetoric) is alarming. What explains similar patterns in the countries as diverse, with distinct national traditions and history? In the late 1980s-90s the Eastern European countries were engaged in the parallel processes of democratization (from autocracy to democracy) and marketization (from planned to market economy). ${ }^{3}$ The magnitude of these process which meant restructuring of the core principles of the organization of the society was particularly painful and dramatic for most post-Communist states. 
The radical transformation of societies usually leads to a reaction. However, the size of the reaction depends upon particular structures of respective societies, particularly the number and organization of the so-called reforms losers (Hellman 1998). In more industrialized countries, which were more integrated in the European markets to begin with, the transformation may have provoked less resistance. In more rural societies, whose economies were more dependent on the Soviet Union, the reforms led to a bigger shock and stronger resistance from certain societal groups.

The concentration of the modernization losers and their respective size, however, varied from country to country. Horowitz (2000) who compares the market transitions in Poland, Hungary and Czech Republic notes that while the concentrated interest groups losing from market reform - particularly heavily subsidized sectors such as agriculture and inefficient heavy industry - were largest in Poland and smallest in the Czech Republic. In Poland such interest groups were also most well-organized, and least well-organized in the Czech Republic. Eventually in both Poland and Hungary the agricultural sector and state sector industries were forced to fend for themselves. In Hungary the socioeconomic cost of the market reforms for different groups was in some respects exaggerated by the gradualist approach chosen by the ruling elites (Bartlett. 1997). The outcome of the transition in these two countries was the emergence of resentful and a relatively well organized groups, which lost most in the result of the transformation and hence were most vulnerable to the populist slogans. As result of these structural disparities both Hungary and Poland lost a significant amount of employment between the start of transformation and late 1990s (Dallago and Rosefielde 2016). Later the less developed eastern and north-eastern regions with highest unemployment levels of both countries ended up constituting the main support of the populist leaders utilizing the conservative agenda. ${ }^{4}$

In Russia the reforms turned out even more painful due to structural imbalances in different sectors of post-Soviet economy and less significant integration into the European markets by the start of the transformation (comparing to Poland and Hungary). Russia's manufacturing sector was particularly uncompetitive internationally and oriented toward domestic consumption. Person and Landry (2016) show that as people were socialized into the new economic and political system after the Soviet collapse, their patterns of political participation were set by the economic conditions around them, not just their own individual economic situations and the effect of early transition economics turned out to be very durable. The severity of local economic shocks in the early 1990s exerted an influence on orientations toward political participation nearly 20 years later (Person and Landry 2016).

One of the common findings in political science that the anti-modernization oriented parties tend to rely on so-called "modernization losers" - the groups of the population who suffered most from the modernization processes (Loch and Norocel 2016). Hence the fact that the conservative turn occurred in the countries with larger 
segments of the population particularly hurt by the modernization doesn't seem random.

The same group of modernization losers constitutes one of the most reliable segment of Vladimir Putin's support - a bureaucratic class, pensioners and state employees. In addition, "modernization losers" in Russia are the residents of small, medium and single-industry towns (Loch and Norocel 2016) - the so-called "second Russia" as described by the sociologist Natalia Zubarevitch, which typically votes for Putin, since it appreciates most his policies of creating a strong paternalistic state, large-scale social protection, and "the stability, availability of work and wages". This groups also remembers the 1990s best and most likely to reject the liberal ideas. ${ }^{5}$ Similar voters of smaller and middle-size towns of depressed regions in Poland and Hungary (traditional, conservative, traditionally oriented regions) historically vote for PiS and Fidesz respectively (Berglund 2013).

In all three countries with the "conservative" trend we observe the same dynamics: the larger share of the transformation losers, and a gradual increase of the social nostalgia for the pre-reform period precede the arrival of a soon-to-be conservative leader. Was the frustration with the reforms spread in those countries prior to the arrival of the populist leaders? A ERBD survey of 28 post-socialist countries (Denisova; Eller; Frye; and Zhuravskaya 2007) ${ }^{6}$ sheds some light on this dynamic. During the survey respondents were asked to choose from four possible answers to the question of how, in their opinion, their country had to deal with privatized property. The option "leave everything unchanged", which reflects the choice of people truly satisfied with the privatization reforms, was chosen by a minority of citizens in each country (with a maximum of $45 \%$ of respondents in Estonia). In Russia, Poland, and Hungary, however, among the lowest numbers in Eastern Europe - 20 and less percent of respondents - chose this option. According to a different survey in 2009 (one year prior to Fidesz becoming the ruling party in the country) the number of Hungarians who approved of the market reforms that took place in the country, was one of the lowest in the Eastern Europe. In 2013 (two years before PiS won the parliamentary elections) $60 \%$ of Polish respondents believed that post-Communist transformation came at particularly high price for Poland (Karolewski and Benedikter 2016). This suggests that a higher dissatisfaction with transition manifested already in the second half of the 2000s. The later conservative political turn in these countries was just a logical continuation of this trend. Hence Fidesz and PiS taking power can be interpreted as a certain modernization fatigue in these countries.

Putin's policies in Russia may also be reflective of the accumulated frustration to the transformation processes of the 1990s. Prior to Putin's taking power the social surveys of the late 1990s revealed the reforms fatigue of the Russian society. Alexey Levinson, a sociologist from Russia's Levada-Center, points out that by the end of the 1990s "the share of those who fully and unconditionally embraced the market reforms was quite small. Only later some growth was detected, but it turned out to be quite unstable. 
Symmetrically, the share of citizens who did not accept the reforms surpassed three quarters of the population by the end of Boris Eltsin's presidency. ${ }^{8}$ The end of the 1990s also marks the peak of Russian's nostalgia for the Soviet Union - by the year of 2000 the number of the respondents nostalgic of the Soviet Union reached $75 \%$ (the level which was not overcome until now, the period of intensified propaganda about the "dashing 1990s"). ${ }^{9}$ Given this dynamics of the public mood one can assume that a certain extent of a rollback was to be expected in Russia regardless of what particular elite type was to take power in the 2000s. Arguably, however, the Russian elites took it to some other extreme due to their own political agenda (see below).

In this sense Polish, Hungarian and Russian trajectory may be part of the common process. The accumulated frustration of certain social groups with the results of the political and economic transition in the early 1990s, created some demand for a more anti-liberal conservative change in the Eastern European societies. The respective size of those groups may reflect the timing when the conservative political agenda began to be implemented by the politicians (more anti-modernization oriented groups in Russia determined an earlier rollback). Transformation losers, groups of population particularly hurt by the economic transitions, more susceptible to the populist antiliberal rhetoric, were coopted by the political leaders under the conservative rhetoric. This is partly pronounced through the common reference to the allegedly bad experiences of the 1990s, the so-called "dashing 1990s" (Pomerantsev ${ }^{10}$ by the Putin elites; and in the anti-liberal rhetoric of Victor Orban and Jaroslav Katchinsky. The rejection of the devastating liberalism is complemented by the promises of higher role of state in the economy, increased social protection and redistribution to compensate for the "unfairness" of the neoliberal period.

The political elites of these countries provide a similar response to a similar social demand. From the ideological perspective it means some combination of nationalism, Euroscepticism and accent on the country's own "unique path". The emphasis on the unique values and traditions of a given country by the respective political leaders comes along with an increasing rhetorical aversion towards the broadly defined "west" (particularly the European Union, or the United States or both). The reform fatigue accompanied by the rising discontent against the so-called "west", because the western countries and institutions (IMF, World Bank, western NGOs etc.) are blamed for imposing the "alien western traditions" that are incompatible with the cultural authenticity of the countries in question.

Hence the recent strengthening of the conservative trend among the countries of the Eastern Europe largely represents a reaction to the painful transformation processes of the 1990s, and politicization of this agenda by the political elites. To respond to the existing social demand for more protection against the market and frustration with democracy, the conservative political leaders propose higher redistribution and other populist economic policies accompanied by nationalization of major rent-generating industries (oil and gas in the Russian case). 
The similar conservative trend currently experienced in three countries is due to the comparable social dynamics undergone by Russia, Poland and Hungary. Yet specific response and formulation of conservative ideas is unique to each country, and has to do with the situational (in Huntington's sense) nature of this response. As discussed above, rather than being a distinct ideology conservatism is usually used by the political elites in an attempt to protect certain institutions in light of the disruptive social changes, and ultimately to retain their hold on power.

\section{The Supply Side: The Response of the Elites}

Due to the dual nature of the transition in Eastern Europe frustration with the economic reforms spread over the attitudes of the population towards the political institutions and democracy as well. The skepticism about the functioning of democratic system and the economic development of these countries was politicized and used by the ruling elites to achieve their political goals.

This is why the conservative political elites usually combine the emphasize on a country's "unique path" with rejection of political liberalism of the western European type. The malfunctioning western-type democracy was counteres with the "sovereign democracy" in the Russian case, or the "illiberal democracy" in Hungarian case (Simon 2014). Together with anti-democratic rhetoric the leadership in these countries took specific actions to enhance the role of the executive authorities, destroy checks and balances and contain independent institutions.

The dual nature of the political transformation influenced the fact that the market reforms are perceived in these countries as the "integration in the west" and often guided by the western institutions (the IMF, World Bank). Hence, the reaction to those processes also combines anti-market and anti-democratic trends with Euroscepticism. This also to a large extent explains the anti-western rhetoric by the Russian elites and Euroscepticism of the Hungarian and Polish elites.

At the same time, in most cases the political elites attempted to come up or reemphasize their own "traditional values" contrasted to the "western values". However, the cultural specificity of each country adjust the specific way in which conservatism, traditional values and institutions are understood. In Polish case this is a pre-Communist Polish conservatism, emphasis on the Catholic church and traditional family values. In Hungary - traditional "European" values of a nation, family and religion. ${ }^{11}$ In Russia's case the authorities are attempting to combine some sort of a "traditional" hybrid from the combination of the ideological elements of the Russian empire, Russian Orthodox Church and the Soviet Union (a Russian world combined with post-Soviet revanchism and Eastern Orthodoxy). Below I focus more specifically on the conservative brand which was elaborated and implemented in Russia. 


\section{Historical Evolution of the Russion Conservatism}

The contemporary Kremlin's conservatism was for the first time officially announced in 2009 when the ruling United Russia party that passed a document that specified "Russia's conservatism" as its official ideology. ${ }^{12}$ However, the general trend towards embracing these values started at least since Putin taking power in 2000.

The historical evolution of the conservative tradition in Russia proves the initial approach of this paper to conservatism as fundamentally a reaction to massive societal changes. The initial conservative tradition evolved in the Russian Empire as reaction to the French Revolution of the late $18^{\text {th }}$ century. Writings of the early Russian conservatives - Slavophiles (Alexey Khomyakov, Ivan Kireyevsky, lury Samarin, Ivan and Konstantin Aksakov) of the first half of $19^{\text {th }}$ century were focused on the importance of preservation of the unique Russian values (particularly religion) and largely had a romantic orientation topical of the time. ${ }^{13}$

During the first half of the $19^{\text {th }}$ century Russia faced social and national unrest, which led to the Decembrist revolt in St Petersburg in 1825, in which tsarist officers staged a rebellion asking to introduce a constitutional monarchy in Russia. Abroad the Polish population in the western provinces of Russia staged a rebellion in 1831 . To strengthen the authority of the tsar Nicholas I's education minister Sergey Uvarov came up in 1833 the idea of the "official nationality" of the Russian empire combining a triad of "Orthodoxy, Autocracy and Nationality" (later used by the Kremlin at the first part of Putin's rule, which added a more mythological aspect to the Slavophile ideas and "appealed to the system's core constituencies - Orthodox Russians and the rural peasant population - to rally around the tsar" (Hill and Gaddy 2013).

The liberal reforms of the 1860s by the Tsar Alexander II (including the longawaited abolition of serfdom) gave rise to another type of Russian conservatives - the so-called statesmen (Konstantin Pobedonostsev, Lev Tikhomirov) who emphasized the fundamental role of the state in the Russian tradition. Nikolay Danilevsky became famous in 1869-71 following the publication of his milestone work "Rossia I Evropa", in which he developed a theory of cultural-historical types arguing that Slavic ethos and Russia formed a new cultural unit.

Since its origin the Russian conservatism emerged as a philosophical movement challenging both democratic and socialist doctrines, appealing for the authorities to avoid the radical change of the social relationships and enforce tradition on the basis of monarchy and Eastern Orthodoxy. It particularly strengthened following the murder of Russia's liberal reformer tsar Alexander II (which seemed to confirm the conservative ideas that the liberal reforms were unfit for Russia and only could only provoke the chaos and disintegration of the country). Another common topic of Russia's conservatism at the time is the western threat to Russian tradition and political independence, and the inapplicability of the European forms of governance for the unique Russian culture. 
The second wave of conservatism emerged in the emigrant circles as a result to the 1917 Revolution in Russia and a radical transformation of the society. Three major subgroups constituted the emigrant thought - the works by Ivan Ilyin, the works by Ivan Solonevich and the Eurasians (Piotr Savitsky, Nikolay Trubetskoy, George Vernadsky, George Florovsky, Lev Karsavin and others). Ivan Ilyin argues that the particular forms of organization and functioning of the state is impossible to understand without understanding the "unique soul" of every nation. Hence to Ilyin different state forms belong to different nations and it's ridiculous to expect the democratic form of governance to belong to each and every country ignoring their traditions and culture. A free democratic form of governance is only applicable to a mature developed rule-abiding nation, otherwise it may destroy a society. Ilyin is particularly focused on Russia's messianic role in world history, preservation and restoration of Russia's historical borders and Orthodoxy, and its protection from the aggression from the western countries that aim to "partition"14 it.

Ivan Solonevich (1891-1953) focused on the idea of people's monarchy - unique features of the national spirit, history and geography shape particular political institutions in every nation. Hence Russia's nationhood, statehood and culture are fundamentally different from Europe and Asia, and create the original Russia's nationalism along with Russian monarchy, church and nation. To Solonevich the loss of Russia's unique national and state traditions led to the disaster - the Revolution of 1917.

Eurasians, who largely drew from the earlier works of Slavophiles, focused on Russia's imperial ambitions of dominating the center of the Eurasian geographical continent. This is why Eurasians were the only ones among the Russian emigres to embrace the establishment of the Soviet system, which augmented Russia's power and territory, and could ultimately transform into a Eurasian power. They also stressed the origin of the 1917 Revolution as a result of a split between the Russian society and the elites, and the loss of the cultural idea of nation-state. In their view, socialism provided a release for the accumulated social discontent. Hence Eurasians view the victory of Bolsheviks as some historical necessity, and even historical justice.

The third wave of conservatism emerged as an ideological reaction to the transformation and ultimate collapse of the Soviet Union in the late 1980s and the liberal political and economic reforms of the early 1990s. Due to the country's repeatedly interrupted philosophical tradition, the third wave of the conservatism combined incongruent blurred and eclectic ideas and movements with a focus on the idea of the unchanging, eternal values of Russia. To a large extent this trend was a reaction of some groups of the Russian society to the loss of the "ancient" Soviet order, their concern for stability, preservation of tradition, and aversion to the anarchy. Since the emergence of the third wave conservatism this movement opposed Russia's liberals, and embraced instead the values of anti-individualism, collectivism, anti-westernism and anti-globalism. The most prominent representatives of the "third wave" of conservatism include writers Valentin Rasputin, Alexander Prokhanov, Vadim Kozhin, 
Alexander Solzhenitsyn, mathematician Ilya Shafarevich, philosophers Alexander Zinoviev, publicist Sergey Kara-Murza, a number of Russian Orthodox priests. A school of neo-Eurasianists, included theorists such as Elgiz Pozdnykov, Alexander Dugin, Natalya Narochnitskaya and Alexander Panarin. As pointed out by Marlene Laruelle, since early 1990s the neo-Eurasianists were primarily looking to compensate for the Soviet collapse, offering a way of thinking about the suddenly fragmented post-Soviet space as a unity without referencing Communism (Laruelle 2015). However, the work of scholars like Alexander Solzhenitsyn was particularly focused on pre-Soviet Russia, the preservation of the traditions of the Russian Empire. Others put special emphasis on the works of the philosophers of the past, including Ivan Ilyin, and Ivan Solonevich among the most cited authors.

In light of the dual democratic and market transition of Russia in the early 1990s, the third wave conservatives focus on the critic of the western political structures and democracy, discuss the threats the imposition of the western model represents for the Russian nation. To the extent that Russia in these theories is portrayed as being under some kind of threat from exploitation by the western countries, these ideas remind of the Latin American dependency theory. According to contemporary conservatives the imposition of the western political and economic model benefits the western proprietors of the "financial mechanism" that operates the total dictatorship in the west and aims to subordinate the rest of the world. Another common narrative is the fundamental role of the Eastern Orthodox tradition for formation of the unique Russian statehood, economy and spirit. Hence this branch of thought is eagerly opposed to the western religious proselytism, promotion of non-traditional religious cults. Often brought up is the Eurasian idea of the exclusivity of a "Slavo-Turkic" super-ethnos which allegedly lives in the geopolitical space of Eurasia and spiritually surpasses the west that have exhausted its potential by now. In general, the emphasis on Russia's cultural opposition to the west and the inevitable soon collapse of eth United States ${ }^{15}$ is particularly strong among the new conservatives. Alexander Dugin writes about a constitutive cleavage of Atlanticism/Eurasianism, which divides Europe into the proAmerican Atlanticist group and the Eurasian Heartland. Alexander Prokhanov and Mikhail Yuriev emphasize on need for the restoration of the Russia's empire, which could also include other territories along with the post-Soviet space.

\section{Putin's Application of the Russion Conservatism}

It is unclear to what extent Vladimir Putin's thinking was influenced by conservative ideas upon his becoming the President of Russia for the first time. By various accounts he was not alien to such lines of thought. During the years of his KGB training Putin was likely exposed to the conservative thinkers, such as Eurasians popular in Russia's security circles even in the Soviet period. ${ }^{16}$ Putin may have also come under the influence of the Russian émigré circles in Germany during his residence there, in 
particular the National Alliance of Russian Solidarists, where Putin could have been exposed to the ideas of Russia's conservative thinkers.

The influence of conservatism on Putin's thinking, however, was straightforward almost immediately after Putin's coming to power. As early as in his 1999 policy manifesto "Russia at the Millennium" Putin proposed 'grounding' or 'domesticating' substantive principles of the liberal ideology for the purposes of arriving at a (typically conservative) 'organic synthesis' (Prozorov 2004): "We can hope for the future if we can organically synthesize the universal principles of market economy and democracy with the Russian reality"(Putin 1999). In his article Putin stressed that universal norms of democracy were not Russian and have even damaged Russia's political development. Putin also immediately openly reembraced Russian Orthodoxy and the Orthodox Church", stressing "the importance of rediscovering his Orthodox faith"(Hill and Gaddy 2013). Putin's interest in Ilyin and his writings became apparent since 2005 through Putin's continuing references to llyin in his national addresses in 2005, 2006, and 2007. In 2005 Ilyin's remains were reburied at the necropolis of Donetsk monastery (the decision unlikely to have been made without the President's participation).

Yet initially the conservative trend wasn't as pronounced largely due to existence of liberal groups, legacy of the presidency of Boris Yeltsin within Putin's closest circles. Several most influential ideological schools in Russia influenced the policy-making following the collapse of the USSR (Zevelev 2014). Initially the liberal westernizers under Boris Yeltsin's rule made most foreign policy decisions. However, by the end1990s their influence diminished and made way for the realist-statists. Founded by Yevgeny Primakov, the realist-statists is the group who became disappointed with the western approach to Russia in the 1990s (in light of Kosovo bombings and NATO's eastern expansion) and may be described as part of the Russian conservative tradition. These are defensive realists who support restoring Russia's status as an influential global player in a multipolar world, strengthening its spheres of influence in the postSoviet space and reducing the U.S. global dominance. Russian statists consecutively accumulated power during the first years of Putin's rule. Mid-2000s, when Putin was finally able to get rid of the most influential liberal players from Yeltsin times, coincide with the increasing influence of the Russian statists in the Kremlin, who sought to secure Russia's full sovereignty by blocking foreign attempts to interfere in Russia's internal affairs from the U.S. seen as promoter of regime change and "colored revolutions" (Hill and Gaddy 2013) by increasing Russia's influence abroad initially through softpower approaches.

Around 2007 the Kremlin, increasingly disappointed with the west and more and more influenced by the realist-statist thinking, launched a new initiative, designed to promote abroad Russia's soft-power and values that would challenge the standard Western tradition. The initiative was to be achieved through several instruments created by the Kremlin. First, the state's control of the country's major television networks and launching new media networks abroad (Russia Today was launched in 
2005), which would spread a uniform Russia's interpretation of the events at foreign audiences. Second, several newly launched NGOs would familiarize the foreign expert communities with the Russia's culture and policies, such as the Russian World Foundation launched in 2007 and designed to spread the Russian language and culture under the supervision of a conservative political scientist Vyacheslav Nikonov, or the Institute for Democracy and Cooperation with offices in New York and Paris, headed by conservative politician Natalia Narochnitskaya.

In the domestic politics the process culminated in the reformulation of Uvarov's doctrine as "sovereign democracy" - a term first championed by Deputy Chief of Staff Vladimir Surkov, as a response to the increasing western concerns regarding human right violations in Russia. The idea of sovereign democracy stresses Russia's independence of the west, and communicates the idea of Russia's strong and powerful state with some references to the tsarist autocracy (Hill and Gaddy 2013). Putin's continuous emphasis on the historical role of the Russian Orthodox Church for the country fit in that picture. In 2006 Russia's first deputy prime minister Sergei Ivanov published an article elaborating that idea. While in line with Russia's conservative tradition he presented the current world as a competition between different value systems, Ivanov specifically drew on Count Sergei Uvarov's famous triad of "Orthodoxy, Autocracy, Nationality" (Aslund 2008) to argue that the "new triad of Russian national values is sovereign democracy, strong economy, and military power" (Ivanov 2006).

With President Medvedev in 2009-2011 Russian liberal school became slightly more noticeable again. Yet the fundamental change in the doctrine came with Putin's third term in 2012, yet again as a reaction to the big societal changes. The 20112012 street protests once again indicated the failure of the liberal approach: the Kremlin's concerns about the west trying to create a Color revolution in Russia along with a decision to contain the liberal protest resulted in a fundamental change of the approach. Most of the 2000s despite occasional flirting with different ideologies (Vladislav Surkov's attempts to elaborate the concept of the national idea and a "sovereign democracy"), the Kremlin avoided integrating specific ideological policies into its domestic policies: there was little need for it, since the majority of the Russians were satisfied with the economic growth and increasing opportunities. Yet the 2008 crisis and resulting growth decline has created the increasing people's frustration with the country's direction, which together with a shock from Putin's announcement about his return to power in September 2011 and unprecedented falsifications of the 2011 election contributed to the outburst of protest at the end of the year. ${ }^{17}$ The Kremlin felt threatened. In light of the presidential elections upcoming in May 2012, the Kremlin used the available conservative ideas to create with a more coherent and pronounced state ideology to justify its tougher anti-wester stance and prosecution of the dissent. Shortly after the protests escalated in December 2011 in light of the rigged parliamentary elections and the ruling United Russia received one of its worst results in history, Vyatcheslav Volodin replaced Vlasislav Surkov at the position of the first deputy 
chief of President Vladimir Putin's staff. The first deputy chief of staff is responsible for managing the internal affairs and known as "the Kremlin's political strategist". Volodin replaced Surkov's flirting with conservative ideas into a blunt but effective promotion of conservatism on all levels. It is at this point that the Kremlin implemented a more radical conservative shift of its domestic and foreign policies.

The new approach had two goals: contain the domestic protest and substitute the state legitimacy previously ensured by continuous economic growth with a new legitimacy coming from the conservative ideology; counteract the alleged western attempts to change the regime with ensuring Putin's hold on power. The promotion of conservative ideology began to be implemented on a larger scale. On the government level, the Kremlin by offering volumes of Russian conservative philosophers to the regional governors and other policy-makers in Russia and organized a series of the educative seminars on Russian conservative thought in the Kremlin. In January 2013 mandatory teaching of religion in public schools was introduced in Russia.

The change is quite clearly pronounced in a set of Putin's own pre-electoral articles published prior to 2012 presidential election, where he specifically outlines such components of the new conservative trend as the importance of Russia's distinctive civilization, honor, values and spiritualty, and a need to resist the outside attempts to destroy Russia's traditional cultural and political track. In these articles Putin actively quotes from Ilyin and Berdiaev, and emphasizes Russia's cultural distinctiveness: "This is what Ivan Ilyin wrote about Russia's special character: "The core, the fabric of this great civilization are the Russian people, the Russian culture. It is this core that different provocateurs and our opponents try to destroy while discussing "the Russians' right to self-determination". ${ }^{18}$ The distinctiveness of Russia is used to justify the inapplicability of the western political institutions (aka democracy, power alternation), and ultimately Putin's stay in power.

When it comes to the international politics, Putin's articles echo llyin's speculations on the attempts by the western powers and NATO to undermine Russia's sovereignty. "Regional and local wars flash before our eyes. There emerge new areas of instability and artificially heated, controlled chaos. Deliberate attempts are made to provoke such conflicts in the immediate vicinity of Russia's borders and allies."19 Now compare that quote to Ivan Ilyin's quote: "Lets immediately accept that Russia's partitioning prepared by the international backstage has absolutely no reason behind, or real spiritual or political considerations besides revolutionary demagogy, absurd fear of a unified Russia and inveterate enmity towards the Russian monarchy and the Eastern Orthodoxy. We know that Western nations don't understand and don't tolerate Russian identity... They are going to divide the united Russian 'broom' into twigs to break these twigs one by one and rekindle with them the fading light of their civilization. They need to partition Russia to equate it with the West, and thus destroy it: a plan of hatred and lust for power ..."20. 
On the policy level Putin's return in 2012 and appointment of Volodin at the position of the internal strategist coincided with a harsh attack against the "western" NGOs, independent non-profits and media outlets, perceived as "the agents of the foreign influence" with an ultimate goal of destroying the regime. In July 2012 Russia's State Duma (known to be passing the laws crafted in the presidential Administration) passed a Foreign Agents law, which obliges the non-profit organizations that receive foreign donations and engage in "political activity" to register and declare themselves as foreign agents. 2011 also marked the launch of the Eurasian Union project, which Putin advertised as the project aimed at reintegrating the post-Soviet space under its leadership is Russia's "natural" geopolitical destiny; but also engage in criticism of liberal principles and call on Europe to remember its "true" (conservative) values (Laruelle 2015). Marlene Laruelle stresses that this project accelerated the previous trend of rehabilitating Russia's Soviet and imperial past, in the hope that citizens' pride in their country and its legacy would be replicated as support for the regime (Laruelle 2015).

Yet the ultimate affirmation of the conservative trend came in 2014 following the Euromaidan Revolution in Ukraine. The events in Ukraine scared the Kremlin, as a direct indicator of the threat of the Color revolutions approaching the Russian borders. The decision to annex Crimea, gave the Kremlin a pretext for (using Zevelev's terms) a "securitization of the national identity" (Zevelev 2014). While Russian conservatism always had an element of Russia's imperialism in it, the specific incorporation of these ideas into the Kremlin policy-making did not take place until mid-2010s. Until the Russian-Ukrainian war the discussions of the new Russian national identity were not integrated into Russia's foreign policy. The revolution in Ukraine allowed (and from the Kremlin's perspective even forced) Russia to securitize the question of identity; that is, to make it one of the issues critical for the survival of the Russian nation and statehood.

In March 2014, Putin's press secretary Dmitry Peskov called the Russian President a guarantor of security for the Russian world (Russkyi Mir). From now on the concept of the Russkyi Mir was reinterpreted not just a popularization of Russia's culture and language, but as the shift from the nation-state level to the larger than as nation-state community becomes. This change in the Kremlin's official perception of its zones of responsibility justified the annexation of Crimea, war in Ukraine and became very pronounced on the policy level. The Ukrainian events coincided with the strengthening of the positions in the Kremlin policy-making circles (dominated by the realist-statesmen at the time) of the group of neo-imperialist (including the neo-Eurasian Alexander Dugin), who emphasized the need to reestablish the Russia's positions in the world and to create a buffer zone of post-Soviet protectorates along Russia's new borders (Zevelev 2014). The Russian world concept, which integrated the neo-Eurasianist concepts, pictured Russia as not limited by its national borders, as a certain hybrid of a Russian empire and a Soviet Union. Around the same time the Kremlin also coined the term "Novorossia" to describe the allegedly Russians-populated territories located outside of the national 
Russian borders in Ukraine (the term itself is a completely artificial construct created for purely instrumental reasons ${ }^{21}$ ).

Mikhail Yuriev's book was rumored to be very popular in Putin's close circles around that time, pictures this neo-imperial image of Russia. In a utopian fantasy "The Third Empire: Russia that Ought to Be" Yuriev describes how 2054 world order was established, and the process has a striking resemblance with the 2014 Ukrainian events. It begins with a Recovery period of 2000-12, when the Great Russia starts its resurgence under the rule of Vladimir II the Restorer. Importantly the First Expansion that leads to reunification of significant territory occurs when Eastern and Southern Ukrainian regions rebel against west-organized Orange revolution (supported by western Ukraine). To help the revolting Ukrainians (that want to rejoin Russia) Vladimir II offers to include their Eastern territories into Russia. He then passes a referendum on those territories, and replaces the Russian Federation with the Russian Union (refer to the Custom Union) that also includes Belarus, Prednestrovie, Kazakhstan, Turkmenistan, South Ossetia and Abkhazia. Yuriev's book was published in 2006 (prior to the Georgian war and the de-facto annexation of South Ossetia and Abkhazia) weirdly predicted the events that followed, which suggests that it had a good grasp on the thinking in the Kremlin policy-making circles (Snegovaya 2014).

Although the Russkyi Mir concept along with the collapse of the Novorossia project eventually failed and is currently put on hold, it had a serious impact on the evolution of the conservative trends in Russia. The war in Ukraine coincided in tougher prosecution of any dissent and opposition in Russia portrayed by the state propaganda as the western accomplices aiming to destroy the country, increase in state propaganda levels on the main state-controlled TV channels, and the emergence of a group of ultra-conservative Russian deputies (including Irina Yarovaya, Elena Miszulina, Vitaly Milonov) with a set of anti-liberal bills, many of them became laws. These legislatve initiatives included among others Milonov's controversial legislation banning the vaguely defined "promotion of non-traditional sexual relations"; Mizulina's 2012 Internet Restriction Bill; 2013 Anti-Magnitsky bill denying Americans the right to adopt Russian children; 2013 prohibits the distribution of "propaganda of nontraditional sexual relations; 2014 bill preventing women from entering higher education before giving birth; Yarovaya's laws imposing harsh new restrictions on religious groups and internet providers etc.)

Generally, domestically such policies have been a success. The use of the conservative ideology and annexation of Crimea bumped up Putin's ratings, Portraying the Russian opposition leaders as west-funded traitors destroyed the popular support for the opposition, which culminated in its complete failure to win any legislative seats in the last parliamentary elections in September 2016. The new Duma elected in 2016 featuresan even larger group of ultra-conservative politicians, including a TV host Peter Tolstoy, a Stalin-admirer Elena Yampolskaya, a writer Sergei Shargunov, which suggests that the conservative track in Russia's domestic policies will continue. 
However, it is unclear to what extent the foreign policy of the Kremlin has been a success as well. Through aggressive rhetoric and anti-western stance in Ukraine and Syria Putin disrupted the relationships with the west, while the western sanctions on Russia damaged Russia's economy, which represents a risk for Putin's rule in the future. Yet until recently the confrontation with the west allowed him to position himself as a strong leader in the eyes of the Russian people, hence providing a boost to his popularity. If the ultimate goal of conservatism is to preserve existing institutions and the elites hold on power, so far the goal was achieved.

\section{Conclusion}

In this paper I discuss the conservative turn that took place in Russia in the last 15 years. I provide the bottom-up and the top-down explanations to this phenomenon.

Russian dynamics does not look that surprising and unique when compared with similar trajectories of other Eastern European countries. Such conservative reaction looks like an expected response to the political and economic transitions the postCommunist societies underwent in the 1990s. Some Latin American countries (primarily, the Andes - Bolivia, Colombia, Venezuela) went through a similar process of the so-called Crisis of Democratic Representation following the implementation of neoliberal economic and political reforms in the 1980s due to similar causes (Mainwaring; Bejarano; and Leongómez 2006).

However, the reactionary response in all three countries of interest started in different period (in Russia before all) and had a similarly varied depth of socio-political reaction. The extent of the reaction (and its chance to roll back into a non-democratic system) likely is partly defined by the depth of the original transformation of the society. Poland, among the most modernized of the analyzed cases, the rollback process has just started, and will likely be the least profound (as recently illustrated by successful popular ban on the abortion law). By contrast, in Russia where the modernization processes were the most superficial and faced the strongest social resistance, the old political elites could regain power sooner and roll back the society deeper. The hope remains that along with other countries at similar development stages Russia will be able to return to modernization track. 


\section{Notes}

' Rightwing Law and Justice Party Wins Election. Guardian, October 27, 2015. http://www.theguardian. com/world/2015/oct/27/poland-law-justice-party-wins-235-seats-can-govern-alone

2 http://www.politicalcapital.hu/wp-content/uploads/PC_Study_Russian_Influence_Slovakia_ENG.pdf;

Marlene Laruelle Lóránt Győri Péter Krekó Dóra Haller Rudy Reichstadt "From Paris To Vladivostok". The Kremlin connections of the French far-right.// http://www.politicalcapital.hu/wp-content/uploads/PC_ Study_Russian_Influence_France_ENG.pdf; Marching Towards Eurasia. The Kremlin connections of the Slovak far-right Péter Krekó Lóránt Győri Daniel Milo Juraj Marušiak János Széky Anita Lencsés// http:// www.politicalcapital.hu/wp-content/uploads/PC_Study_Russian_Influence_Slovakia_ENG.pdf

${ }^{3}$ In fact the transition also involved a separate process of nation state-building, which I omit for the purposes of this paper. /

${ }^{4}$ Снеговая М. Правый пововрот: такой ли уж особый у России путь? 28 апрел, 2016// http://www. rbc.ru/opinions/politics/28/04/2016/5721f97b9a79471753dacefc

5 Наталья Зубаревич. Четыре России и новая политическая реальность. Polit.ru, 17 января 2016// http://polit.ru/article/2016/01/17/four_russians/

6 Ростислав Капеллюшниклов. Собственность без легитимности? 27 марта 2008, polit.ru// http:// polit.ru/article/2008/03/27/sobstv/

7 End of Communism Cheered but Now with More Reservations. Pew Research Center, November 2, 2009// http://www.pewglobal.org/2009/11/02/end-of-communism-cheered-but-now-with-morereservations/

8 Левинсон А.Г. Общественное мнение о реформах начала 1990-х годов. История новой России, http://www.ru-90.ru/node/1129

9 Почему почти 60 процентов россиян «глубоко сожалеет» о распаде СССР. Иносми, 24.12.2009// http://inosmi.ru/social/20091224/157182941.html

${ }^{10}$ Peter Pomerantsev: Putin is a media fiction. He is the first president entirely created through media. (Mymedia, 25.09.2015)// http://mymedia.org.ua/en/articles/media/pomerantsev_presentatsiya_knigi. html

${ }^{11}$ Orbán, in UK speech, calls for return to traditional European value. Politics.hu, October 10th, 2013

//http://www.politics.hu/20131010/orban-calls-for-traditional-values-to-meet-modern-challenges/

12 "Российский консерватизм" стал официальной идеологией "Единой России". (RIA новости, 21.11.2009)// https://ria.ru/politics/20091121/194856090.html

${ }_{13}^{13}$ А.В. Репников. Консервативная модель переустройства России. Доклад на научном семинаре «Россия в условиях трансформаций». См.Вестник Фонда развития политического центризма, июнь 2000, № 2 (23). Россия в условиях трансформаций. Историко-политологический семинар. Материалы. Вып. 2. М., 2000. C.4-28.

${ }^{14}$ Ivan Ilyin's 1950 piece 'What Does Russia's Partitioning Mean to the World?

${ }_{15}^{15}$ Александр Дугин. Основы геополитики. Москва, Арктогея,2000// http://arctogaia.com/public/ osnovygeo/geop4-7.htm

${ }^{16}$ История России XX век. Эпоха сталинизма (1923-1953), том ॥, под ред.А.Б.Зубова.- Москва, Издатеоьство «Э». 2016

17 Волков Д. Лекция «Основания политического порядка и возможность демократических перемен в России», 01 ноября 2015 (прочитанна 19 февраля 2015 в рамках Открытого гражданского лектория Сахаровского центра), http://polit.ru/article/2015/11/01/foundation/

${ }^{18}$ Владимир Путин. "Россия: национальный вопрос" (Незавиимая газета, 23.01.2012)

${ }^{19}$ Владимир Путин. «Быть сильными: гарантии национальной безопасности для России» (Российская газета, 20.02.2012)

${ }^{20}$ Ivan Ilyin:'What Does Russia's Partitioning Mean to the World?',"Our Tasks,"1950

${ }^{21}$ http://www.vedomosti.ru/newspaper/articles/2014/05/19/sozdanie-novoj-politicheskoj-realnosti 


\section{References}

ASLUND, A. (2008) Putin's Lurch toward Tsarism and Neoimperialism: Why the United States Should Care. Demokratizatsiya, The Journal of Post-Soviet Democratization 16(1):17-25.December, https://www2.gwu.edu/ ieresgwu/assets/docs/demokratizatsiya\%20 archive/ GWASHU_DEMO_16_1/2T54R87451R1217G/2T54R87451R1217G.pdf

BARTLETT, DAVID (1997). The Political Economy of Dual Transformation. Market Reform and Democratization in Hungary. The University of Michigan

BERGLUND, STEN (ed) (2013) The Handbook of Political Change in Eastern Europe. Edward Elgar Publishing Inc., - P.196

BLOOR, D. (1997) 'The Conservative Constructivist' History of the Human Sciences, 123-5.

DENISOVA, IRINA; MARKUS ELLER; TIMOTHY FRYE; and EKATERINA ZHURAVSKAYA (2007)

"Who Wants to Revise Privatization and Why? Evidence From 28 Post-Communist Countries". CEFIR and NES Working Papers. n 105

GOSTYŃSKA-JAKUBOWSKA, AGATA (2016) Poland: Europe's new enfant terrible? Bulletin Article by Center for European Reform, 22 January 2016// https://www.cer.org.uk/sites/default/ files/bulletin_106_ag_article1.pdf

HELLMAN, J.S (1998) Winners Take All: The Politics of Partial Reform. World Politics, Volume 50, Issue 2

HILL, F AND GADDY C (2013) Mr Putin : Operative in the Kremlin. The Brookings Institution HOWORITZ, S. (2000) National Identity and Liberalizing Consensus in Poland, Hungary and The Czech Republic. The Polish Review, Vol. 45, No. 2, pp. 197-216

HUNTINGTON, SAMUEL P (1957) Conservatism as an Ideology. The American Political Science Review, Vol. 51, No. 2 (Jun), pp. 454-473// https://www.jstor.org/stable/pdf/1952202.pdf

IVANOV, SERGEI (2006) "Triada natsionalnykh tsennostei" [The triad of national values], Izvestiya, July 13, 2006. Available at http://www.izvestia.ru/politic/article3094592/(accessed January 10, 2008).

KAROLEWSKI, IRENEUSZ AND ROLAND BENEDIKTER (2016) Is Poland Really Lost? Poland's Contested Governance Reforms and the further Role of the Central Eastern European area (CEE) in the EU, Working Paper for The Europe Center, Freeman Spogli Institute for International Studies, Stanford University, https://fsi.fsi.stanford.edu/sites/default/files/poland-cee-and-eukarolewski-benedikter-2016-final3.pdf

LARUELLE, M. (2015) Eurasia, Eurasianism, Eurasian Union TERMINOLOGICAL GAPS AND OVERLAPS PONARS Eurasia Policy Memo No. 366, July, http://www.ponarseurasia.org/sites/ default/files/policy-memos-pdf/Pepm366_Laruelle_July2015.pdf

LOCH, DIETMAR AND CRISTIAN NOROCEL (2016). The Populist Radical Right in Europe A Xenophobic Voice in the Global Economic Crisis, Europe's Prolonged Crisis: The Making or the Unmaking of a Political Union (Palgrave Studies in European Political Sociology, Palgrave Macmillan; 1st ed. 2015 edition (April 29, 2016)

MAINWARING, SCOTT; ANA MARÍA BEJARANO; AND EDUARDO LEONGÓMEZ eds (2006) The Crisis of Democratic Representation In The Andes, Stanford, California, Stanford University Press

MANNHEIM, KARL (1953) "Conservative Thought," Essays on Sociology and Social Psychology, ed. Paul Kecskemeti (New York, 1953), pp. 98-99.

MÜLLER, JAN-WERNER (2016) The Problem with Poland. The New York Review of Books, http:// www.nybooks.com/daily/2016/02/11/kaczynski-eu-problem-with-poland/ 
MULLER, JERRY. (Ed) (1997) Conservatism: An Anthology of Social and Political Thought from David Hume to the Present. Princeton University Press, Princeton, New Jersey, - p.5

OFFE, CLAUS (1991). Capitalism by Democratic Design? Democratic Theory Facing the Triple Transition in East Central Europe. Social Research, 58(4), p.865-881. January, pp. 203-234

PERSON, ROBERT and PIERRE LANDRY (2016) The Political Consequences of Economic Shocks, Problems of Post-Communism, 63:4, 221-240

ORBÁN, in UK speech, calls for return to traditional European value. Politics.hu, October 10th, 2013. //http://www.politics.hu/20131010/orban-calls-for-traditional-values-to-meet-modernchallenges/

PROZOROV, SERGEI (2004) Russian Conservatism in The Putin Presidency: The Dispersion of a Hegemonic Discourse. Working Paper 2004/20. Danish Institute for International Studies// C:/ Users/809450/Downloads/RUSSIAN_CONSERVATISM_IN_THE_PUTIN_PRESID\%20(1).pdf PUTIN, VLADIMIR (1999), "Rossiya na Rubezhe Tysyacheletiy." Nezavisimaya Gazeta, Dec. 30. ROSEFIELDE, STEVEN and BRUNO DALLAGO (2016). Transformation and Crisis in Central and Eastern Europe: Challenges and Prospects. New York, NY Routledge

SNEGOVAYA, MARIA (2014) How Putin's worldview may be shaping his response in Crimea. Monkey Cage, Washington Post, march 2, 2014, https://www.washingtonpost.com/news/ monkey-cage/wp/2014/03/02/how-putins-worldview-may-be-shaping-his-response-in-crimea/

ZOLTAN, SIMON (2014) Orban Says He Seeks to End Liberal Democracy in Hungary. Bloomberg, 28.07.2014 http://www.bloomberg.com/news/articles/2014-07-28/orban-says-he-seeks-to-endliberal-democracy-in-hungary

ZEVELEV, IGOR (2014) The Russian World Boudaries.Russia's National Identity Transformation and New Foreign Policy Doctrine. Russia in Global Affairs, Moscow, April

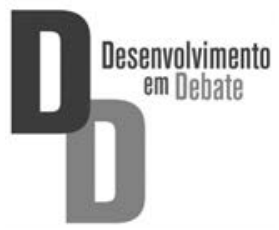

